\title{
Performance of Children in Phonemic and Semantic Verbal Fluency Tasks
}

\author{
Gilmara de Lucena Leite - Universidade Federal do Rio Grande do Norte, Natal, Brasil \\ Izabel Augusta Hazin Pires - Universidade Federal do Rio Grande do Norte, Natal, Brasil \\ Laura Carolina Lemos Aragão - Universidade Federal do Rio Grande do Norte, Natal, Brasil \\ Artemis Paiva de Paula - Universidade Federal do Rio Grande do Norte, Natal, Brasil \\ Ediana Rossely de Oliveira Gomes - Universidade Federal do Rio Grande do Norte, Natal, Brasil \\ Danielle Garcia - Universidade Federal do Rio Grande do Norte, Natal, Brasil \\ Priscila Magalhães Barros - Universidade Federal do Rio Grande do Norte, Natal, Brasil \\ João Carlos Nascimento de Alencar - Universidade Federal do Rio Grande do Norte, Natal, Brasil \\ Helenice Charchat Fichman - Pontifícia Universidade Católica do Rio de Janeiro, Rio de Janeiro, Brasil \\ Rosinda Martins Oliveira - Universidade Federal do Rio de Janeiro, Rio de Janeiro, Brasil
}

\begin{abstract}
This study investigated the performance of children from the Brazilian Northeast region, from 7 to 10 years in phonemic and semantic verbal fluency tasks. The participants were 102 subjects (62 girls and 40 boys) who performed three phonemic and three semantic fluency tasks. The results were submitted to correlational and variance analysis to investigate the influence of the variables age and gender on the subjects performance. There was no effect of gender on the results. Significant contrasts between age groups were found, and better performance was observed on phonemic tasks. Also, the performance in this task changed along development, in contrast to what happened with the semantic fluency. The findings seem to be in accordance to neurodevelopmental aspects, taken into account that explicit memory systems show more precocious maturational course, with earlier consolidation, in comparison to the executive functions and frontal lobes, which go on developing until adult ages. Keywords: child development, verbal fluency, neuropsychological assessment
\end{abstract}

Desempenho de Crianças em Tarefas de Fluência Verbal Fonêmica e Semântica

\begin{abstract}
Resumo
O presente estudo investigou o desempenho de crianças da região Nordeste, entre 7 e 10 anos, em tarefas de fluência verbal fonológica e semântica. Participaram da pesquisa 102 sujeitos de ambos os sexos, os quais realizaram três tarefas de fluência fonológica e três de fluência semântica. Os dados encontrados foram submetidos a análises correlacionais e de variância, considerando a influência das variáveis idade e sexo sobre o desempenho dos participantes. Não houve efeito do sexo sobre o desempenho das crianças. Contrastes significativos entre as faixas etárias foram verificados, observando-se melhor desempenho nas tarefas do componente fonológico com o avanço da idade e em comparação com o semântico. Os resultados encontrados parecem estar respaldados por aspectos neurodesenvolvimentais, visto que os sistemas de memória explícita apresentam curso maturacional mais precoce e de consolidação anterior em relação às funções executivas e os lobos frontais, cujo desenvolvimento se estende à idade adulta.

Palavras-chave: desenvolvimento infantil, fluência verbal, avaliação neuropsicológica
\end{abstract}

\section{Desempeño de Niños en Tareas de Fluidez Verbal Fonética y Semántica}

\begin{abstract}
Resumen
El presente estudio investigó el desempeño de 102 niños de la región nordeste, entre 7 y 10 años, en tareas de fluidez verbal fonética y semántica. Participaron 102 sujetos de ambos sexos, que realizaron tres tareas de fluencia fonética y tres de fluencia semántica. Los datos encontrados fueron sometidos a análisis correlacionales y de varianza, teniendo en cuenta la influencia de las variables edad y sexo sobre el desempeño de los participantes. El sexo no influyó en el desempeño de los niños. Fueron verificados contrastes significativos entre las edades, con un mejor desempeño en tareas del componente fonológico a medida que avanza la edad comparándolo con el semántico. Los resultados encontrados parecen estar respaldados por aspectos neurológicos del desarrollo, dado que los sistemas de memoria explícita presentan un proceso de maduración más precoz y de consolidación anterior en relación a las funciones ejecutivas y los lóbulos frontales, cuyo desarrollo se extiende a la edad adulta. Palabras clave: desarrollo infantil, fluidez verbal, evaluación neuropsicológica
\end{abstract}

Verbal fluency is a basic function of language that refers to the ability to produce fluent speech (Lezak, Howieson, Bigler, \& Tranel, 2012). Despite consisting of an essentially linguistic function, its

Disponivel em wnw.scielo.br measures have been widely developed and also used to evaluate executive aspects of verbal behavior, given the observation that performance on tasks of this nature is impaired in patients with bilateral lesions on 
the left and back prefrontal cortex (Lezak et al, 2012; Birn et al., 2010.). With this in mind, this function is widely exploited in the field of neuropsychological assessment, notably through measures based on the Thurstone model (Thurstone \& Thurstone, 1962 as quoted in Lezak et al., 2012) - Originally designed to research brainpower.

Verbal fluency measures require the ability to organize and produce spontaneous responses through rules for the recovery of verbal information under time constraints, involving, in general, the semantic and phonological components. Evidencing this semantic component generally requires participants to produce the largest number of words belonging to a semantic category, the most frequently used being animals, fruits, clothes, colors and birds (Strauss, Sherman, \& Spreen, 2006; Charchat-Fichman, Oliveira, \& Silva, 2011). The field of phonological fluency, in turn, requires the production of a greater amount of words starting with a specific letter, the most commonly used letters being "F", "A" and "S" since they are common phonemes in English, in addition to being contained in the Neurosensory Center Comprehensive Examination of Aphasia (Strauss et al., 2006; Mitrushina, Boone, \& D’Elia, 1999).

The brain frontal regions, as well as components of executive functions, have an important role in the fulfillment of tasks of this nature, (Troyer, 2000; Troyer, Moscovitch, \& Winocur, 1997; Troyer, Moskovitch, Winocur, Alexander, \& Stuss, 1998). To accomplish what is requested, the individual must engage in sequential behavior - which requires maintenance and constant updating of memory, so as not to repeat those behaviors already issued - select the relevant stimulus that will guide the production of responses, inhibiting the wrong answers or the ones already mentioned, and to have enough flexibility to generate new responses and monitor this production (Dias, 2009).

Thus, generation of words under specific criteria is considered a valid measure of assessment of executive functioning, since it requires the flexibility of thought (cognitive flexibility), modifying response sets in accordance with the criteria established by the task; search and systematic recovery of verbal information to the detriment of other stimuli (inhibitory control) while organizing them in categories of words semantically or phonologically related (working memory), establishing categories (clusters) and alternating between new groupings (switching) (Troyer et al., 1997). While there is debate about the taxonomy of executive functioning, the current consensus defines the three executive skills highlighted as central executive functions (Diamond, 2013; Fuhs \& Day, 2011).

Neuropsychological investigations have shown that the coordinated activity of different brain areas, especially the frontal and temporal lobes of the left hemisphere, underlies the management of verbal fluency skills. More specifically, although the two fluency tests (semantic and phonological) recruit these two brain regions, the performance in the semantic domain primarily depends on the recruitment of the temporal lobe (neural substrate of semantic verbal memory - storage, knowledge and grouping of words), while performance in phonological domain depends more predominantly of frontal lobe activation (Birn et al., 2010; Davidson et al., 2008; Baldo, Schwartz, Wilkins, \& Dronkers, 2006; Troyer et al., 1998; Micelli, Caltagirone, Gaianotti, Masulo, \& Silveri, 1981).

The above psychometric characteristics, reinforced by easy application and the need for fewer resources, have contributed to the great interest in the use of verbal fluency tests, both in clinical practice and research in neuropsychology (Charchat-Fichman et al., 2011; Silva, Yassuda, Guimarães, \& Florindo, 2010). This popularity is further reinforced by evidence that such tasks are also sensitive and useful measures in the differential diagnosis of neuropsychiatric disorders, such as Attention Deficit Disorder/Hyperactivity Disorder (ADHD) and Autism Spectrum Disorders (Geurts, Verté, Oosterlaan, Roeyers, \& Sergeant, 2004; Puentes-Rozo, Barceló-Martinez, \& Pineda, 2008; Marzocchi, et al., 2008).

The importance of this measure in the diagnosis of neuropsychology has been accompanied by efforts to establish national and regional normative samples by several Brazilian research groups (Charchat-Fichman et al., 2011; Malloy-Diniz et al., 2007; Brucki \& Rocha, 2004). In this matter, a study with Brazilian samples in the semantic verbal fluency tests in adults with low education, has pointed to the effects of schooling on the performance of individuals in the "animals" category (Brucki \& Rocha, 2004). In addition, a study of verbal semantic fluency task with public school children aged between seven and 10 years indicated an increase in the performance of children with advanced age (MalloyDiniz et al., 2007).

Charchat-Fichman Oliveira and Silva (2011) analyzed the effect of age on verbal fluency tasks in Brazilian children using three categories of phonological fluency "F", "A" and "M" and three categories 
of semantic fluency (animals, clothes and fruit). There was a significant effect of age, with a better performance having been verified with advanced age, both in the fields of phonological and semantic fluency. The results were consistent with previous studies with both Brazilian and international samples (Riva, Nichelli, \& Devoti, 2001; Sauzéon, Lestage, Raboutet, N'Kaoua, \& Claverie, 2004; Koren, Kofman, \& Berger, 2005; Malloy-Diniz et al, 2007; Nieto, Galtier, Barroso \& Espinosa, 2008).

It is observed, however, the absence of normative data within the northeast region of Brazil, which has known socioeconomic and cultural peculiarities when compared to other Brazilian regions. The influence of these variables on cognitive development has been demonstrated in a number of studies, especially with regard to executive functions and language (Ardilla, Rosselli, Matute, \& Guajardo, 2005; Prigatano, Gray, \& Lomay, 2008; Sarsour et al., 2011). In this direction, considering the relevance of such an instrument for neuropsychological assessment and the lack of normative studies covering the northeast region of Brazil, the aim of this study was to investigate the performance of Northeastern children in phonological and semantic verbal fluency tasks.

With this in mind, we opted for the reproduction of a study by Charchat-Fichman et al. (2011), keeping the criteria relating to age of the sample, socioeconomic status, type of school, as well as letters and categories used for structuring tasks. Thus, in addition to the establishment of normative data for fluency tasks in the northeast, a comparative study between the southeast and northeast may be developed, in terms of possible quantitative and qualitative differences in children's performance, contributing to discussions about the influence of sociocultural variables on $\operatorname{cog}$ nitive performance.

\section{Method}

\section{Participants}

The study included 102 children aged between seven and 10 years, 62 girls (mean age $=8.29 \pm 1.05$ ) and 40 boys (mean age $=8.38 \pm 0.98$ ), private school students from the states of Paraiba and Rio Grande do Norte, belonging to socioeconomic classes $\mathrm{C}$ and D (estimated from the monthly family income). For the sample, were selected children placed in regular education (elementary school) whose first language was Portuguese. Were excluded children that had history of medical/psychiatric problems or problems related to the abuse of psychotropic drugs. The information for establishing the criteria were collected through questionnaires taken with parents or legal guardians.

\section{Materials}

Three phonological fluency tasks and three semantic fluency tasks were used. For phonological fluency, the letters used were "F", "A" and "M". In the semantic fluency task, the categories used were "Animals", "Fruits" and "Clothes". To record the participants' responses registration protocols, pencils and audio recorders were used.

Procedures

The children were tested individually as follows: to phonological fluency they were asked to recall as many words as possible beginning with the provided letters (F, A, M) within 60 seconds, with some restrictions such as derivations of the same word, and names. For semantic fluency, the words (animals, clothes and fruits) should be recalled freely without the establishment of restrictions within the 60-second range. The participants' responses were scored from the number of correct words produced for each of the six tasks, following the scoring criteria developed by Charchat-Fichman et al. (2011). All ethical principles were followed, according to Resolution No. 466/2012 of the National Health Council, governing research with human beings.

\section{Statistical Analysis}

The distribution of the data was examined using the Kolmogorov-Smirnov test (KS) and data met the normality hypothesis ( $p>0.05)$. From the independent variables (sex and age) and dependent (rights in " $F$ ", "A", "M", "Animals", Clothes", "Fruits", Total rights in phonological fluency, Total rights in semantic fluency and Total evoked words), a multifactorial model of data analysis was outlined. Therefore, to check interference of the interaction effect of variables Sex and Age of participants on the performance in the tests of verbal fluency, a Multivariate Analysis of Variance (MANOVA) was initially held, considering Pillai's Trace as statistical analysis. Pillai's Trace is notably the most robust among the four methods that can be employed in the multivariate analysis (Quinn \& Keough 2002). For the statistically significant factors, MANOVA was followed by analysis of variance (ANOVA) and post-hoc tests, applying the Bonferroni correction. This approach allows to control the type I error rate that 
would result from multiple comparisons, as well as obtain estimates of the overall multivariate influence of independent variables over the dependent ones, and existing univariate differences within each gender and age groups of the study (Hair, Black, Babin, \& Anderson, 2010). Still, to investigate average differences between the overall scores of Phonological and Semantic Fluency, we used the $t$ test for repeated measures and the Pearson Correlation Coefficient was used to verify possible associations between age and results in tasks of Verbal Fluency. The size of effect was measured by partial eta squared $\left(\eta p^{2}\right)$ for analysis of variance and by Cohen's $d$ for the $t$ test of related measures. All analysis were processed in SPSS 18 for Windows, using significance level of $5 \%(p<0.05)$.

\section{Results}

Analysis of the performance of participants in verbal fluency test, performed by MANOVA showed no interaction effect between gender and age on the performance of the children (Pillai's trace $=0.23 ; \mathrm{F}$ $\left.(27.264)=0,81, p=0.732 ; \eta p^{2}=0.077\right)$. With regard to gender, the analysis also showed no effect of this on the overall performance of the participants $(F(1,94)$ $\left.=1.19, p=0.359 ; \eta p^{2}=0.105\right)$. However, an overall effect of age on the performance of the participants was found (Pillai's Trace $=0.47, \mathrm{~F}(27.264)=1.82, p=$ 0.009; $\left.\eta \mathrm{p}^{2}=0.157\right)$.

In this direction, univariate effects were observed (ANOVA) of age on the three phonological fluency tasks both singularly and in their sum with the following values of $\mathrm{F}$ and $\mathrm{p}$ : the letter " $\mathrm{F}$ " $(\mathrm{F}$ (3.94) $=3.38$; $p$ $=0.022)$; "A" $(\mathrm{F}(3.94)=8.42, p<0.001)$; the letter "M" $(\mathrm{F}(3.94)=5.11 ; p=0.003)$ and in total hits in the phonological fluency test $(\mathrm{F}(3.94)=7.99 ; p<0.001)$. In the semantic fluency test, significant age-related effect was found in the "clothes" (F (3.94) $=3.52 ; p=0.018)$ and in the "fruits" $(\mathrm{F}(3.94)=2.78, p=0.045)$ categories. However there were no significant differences for the "animals" $(\mathrm{F}(3.94)=1.66 ; p=0.181)$ and for total hits in the semantic fluency task $(\mathrm{F}(3.94)=2.39 ; p=0.079)$. The means and standard deviations of these tasks are presented in Table 1.

Analyzing the total sum of the number of hits in the Verbal Fluency test, including the tasks of phonological fluency and semantics, significant effect related to age $(\mathrm{F}(3.94)=9.17, p<0.001, d=1.87)$ was also found. It is noteworthy that the children performed better in the semantic fluency test when compared with the phonological fluency test $(t=16.14$, g.l. $=$ $101, p<0.001)$.

From the post-hoc Bonferroni, significant differences were found in total words generated for the letter " $F$ " in groups of 7 to 10 years $(p=0.015)$; for the letter " $\mathrm{A}$ " in groups of 7 to 10 years $(p<0.001), 8$ and $10(p<0.001)$ and 9 and $10(p=0.012)$, and; for the letter " $\mathrm{M}$ " in groups of 7 and 9 years $(p<0.001)$. In semantic fluency tasks significant differences were observed only in the amount of words produced for the category "Clothes" among the participants of 7 and 9 years $(p=0.046)$, although in the category "Fruits" the comparison between the performances obtained by groups aged 7 and 10 have obtained a p value tending to significance level $(p=0.059)$.

Considering the sum of correct answers in the three tasks of phonological fluency, there were significant differences among the performances of groups of 7 and 10 years $(p<0.001), 8$ and 10 years $(p=0.001)$ and 9 and 10 years $(p=0.02)$. Similarly, the number of hits in all verbal fluency tests revealed significant contrasts between the performance of Groups of 7 and 10 years $(p=0.001), 8$ and $10(p=0.015)$ and 9 and $10(p$ $=0.009)$. We must point out that in all cases, the older age groups had the highest average. Figure 1 illustrates the above results.

The Pearson correlation coefficient was used to assess associations between variables, whose main interest is in the relationship between verbal fluency and Age. Table 2 summarizes these results.

From the table, with regard to correlations between Verbal Fluency tests, there is a strong positive correlation between semantic fluency and the category "Animals" $(r=0.604, p<0.01)$, moderate for "Clothes " $(r=0.559, p<0.01)$, and moderate for "Fruits" $(r=$ $0.540, p<0.01)$. In phonological fluency test, correlations were strong for each task in relation to the sum of correct phonological fluency, yielding the following results: "F" $(r=0.822, p<0.01)$, "A" $(r=0.853, p<$ $0.01)$ and "M" $(r=0.841, p<0.01)$. Correlations were also classified as strong when related to the total of rights in Verbal Fluency and in Phonological Fluency $(r$ $=0.713, p<0.01)$ as well as total rights in verbal fluency and letter " $\mathrm{A}$ " $(r=0.631, p<0.01)$.

With regard to correlations between verbal fluency and age, there is a moderate positive correlation between Age and phonological fluency $(r=0.435, p<0.01)$ and Age and Total scores $(r=0.395, p<0.01)$ and, to a lesser degree, between age and Semantic Fluency $(r=$ $0.224, p<0.05)$. Age still showed moderate correlation 
Table 1

Scores of the Verbal Fluency Tasks among Groups and Comparative Statistic Test (ANOVA)

\begin{tabular}{|c|c|c|c|c|c|c|c|c|}
\hline \multirow{2}{*}{ Variable } & \multirow{2}{*}{ Gender } & \multicolumn{4}{|c|}{ Age (Mean, SD) } & \multicolumn{3}{|c|}{ ANOVA } \\
\hline & & 7 & 8 & 9 & 10 & Gender & Age & Inter-action \\
\hline \multirow{3}{*}{$\mathrm{F}$} & Male & $4.43(1.72)$ & $5.17(1.95)$ & $5.75(1.67)$ & $6.57(1.81)$ & \multirow{3}{*}{$\begin{array}{c}\mathrm{F}=0.05 \\
p=0.827 \\
\eta_{\mathrm{p}}{ }^{2}=0.001\end{array}$} & \multirow{3}{*}{$\begin{array}{c}\mathrm{F}=3.38 \\
p=0.022 \\
\eta_{\mathrm{p}}{ }^{2}=0.097\end{array}$} & \multirow{3}{*}{$\begin{array}{c}\mathrm{F}=0.176 \\
P=0.91 \\
\eta_{\mathrm{p}}{ }^{2}=0.006\end{array}$} \\
\hline & Female & $4.78(1.89)$ & $5.06(2.99)$ & $5.39(1.58)$ & $7.11(3.29$ & & & \\
\hline & Total & $4.68(1.82)$ & $5.11(2.47)$ & 5.54 (1.61) & $7.0(2.75)$ & & & \\
\hline \multirow{3}{*}{ A } & Male & $4.29(1.38)$ & $4.89(1.61)$ & $5.63(2.0)$ & $8.14(3.29)$ & \multirow{3}{*}{$\begin{array}{l}\mathrm{F}=0.785 \\
p=0.378 \\
\eta_{\mathrm{p}}{ }^{2}=0.008\end{array}$} & \multirow{3}{*}{$\begin{array}{l}\mathrm{F}=8.422 \\
p<0.001 \\
\eta_{\mathrm{p}}{ }^{2}=0.212\end{array}$} & \multirow{3}{*}{$\begin{array}{c}\mathrm{F}=0.2 \\
p=0.896 \\
\eta_{\mathrm{p}}{ }^{2}=0.006\end{array}$} \\
\hline & Female & $4.44(2.04)$ & $4.29(2.17)$ & $5.28(2.42)$ & $7.22(2.99)$ & & & \\
\hline & Total & $4.4(1.85)$ & $4.6(1.9)$ & $5.54(2.25)$ & $7.93(3.1)$ & & & \\
\hline \multirow{3}{*}{ M } & Male & $4.43(2.07)$ & $5.78(2.02)$ & $5.88(1.55)$ & $7.14(2.12)$ & \multirow{3}{*}{$\begin{array}{c}\mathrm{F}=1.19 \\
p=0.278 \\
\eta_{\mathrm{p}}=0.013\end{array}$} & \multirow{3}{*}{$\begin{array}{c}\mathrm{F}=5.111 \\
p=0.003 \\
\eta_{\mathrm{p}}{ }^{2}=0.14\end{array}$} & \multirow{3}{*}{$\begin{array}{l}\mathrm{F}=0.112 \\
p=0.953 \\
\eta_{\mathrm{p}}{ }^{2}=0.004\end{array}$} \\
\hline & Female & $3.78(2.36)$ & $4.94(2.07)$ & $5.22(2.39)$ & $7.11(3.3)$ & & & \\
\hline & Total & $3.96(2.26)$ & $5.37(2.06)$ & $5.71(1.9)$ & $7.0(2.99)$ & & & \\
\hline \multirow{3}{*}{$\begin{array}{l}\text { Total } \\
\text { Phonological } \\
\text { F. }\end{array}$} & Male & $13.14(3.71)$ & $15.78(4.05)$ & $17.25(4.59)$ & $21.86(4.6)$ & \multirow{3}{*}{$\begin{array}{l}\mathrm{F}=0.501 \\
p=0.481 \\
\eta_{\mathrm{p}}{ }^{2}=0.005\end{array}$} & \multirow{3}{*}{$\begin{array}{l}\mathrm{F}=7.997 \\
p<0.001 \\
\eta_{\mathrm{p}}{ }^{2}=0.203\end{array}$} & \multirow{3}{*}{$\begin{array}{l}\mathrm{F}=0.089 \\
p=0.966 \\
\eta_{\mathrm{p}}{ }^{2}=0.003\end{array}$} \\
\hline & Female & $13.0(5.21)$ & $14.24(6.55)$ & $16.0(5.36)$ & $21.44(8.21)$ & & & \\
\hline & Total & $13.0(4.77)$ & 15. 0 (5.39) & $16.8(4.79)$ & $21.9(6.78)$ & & & \\
\hline \multirow{3}{*}{ Animals } & Male & $8.57(2.99)$ & $10.39(2.22)$ & $9.75(1.83)$ & $12.71(4.79)$ & \multirow{3}{*}{$\begin{array}{l}\mathrm{F}=0.672 \\
p=0.414 \\
\eta_{\mathrm{p}}{ }^{2}=0.007\end{array}$} & \multirow{3}{*}{$\begin{array}{c}\mathrm{F}=1.66 \\
p=0.181 \\
\eta_{\mathrm{p}}{ }^{2}=0.05\end{array}$} & \multirow{3}{*}{$\begin{array}{l}\mathrm{F}=1.456 \\
p=0.232 \\
\eta_{\mathrm{p}}{ }^{2}=0.044\end{array}$} \\
\hline & Female & $10.39(3.24)$ & $11.65(2.71)$ & $11.06(2.92)$ & $10.56(4.8)$ & & & \\
\hline & Total & $9.88(3.22)$ & $11.0(2.52)$ & $10.79(2.73)$ & $10.64(4.24)$ & & & \\
\hline \multirow{3}{*}{ Clothes } & Male & $4.71(1.8)$ & $8.17(2.98)$ & $6.75(1.58)$ & $8.14(3.44)$ & \multirow{3}{*}{$\begin{array}{l}\mathrm{F}=5.365 \\
p=0.023 \\
\eta_{\mathrm{p}}{ }^{2}=0.054\end{array}$} & \multirow{3}{*}{$\begin{array}{c}\mathrm{F}=3.52 \\
p=0.018 \\
\eta_{\mathrm{p}}{ }^{2}=0.101\end{array}$} & \multirow{3}{*}{$\begin{array}{l}\mathrm{F}=1.938 \\
p=0.129 \\
\eta_{\mathrm{p}}{ }^{2}=0.058\end{array}$} \\
\hline & Female & $7.11(2.82)$ & $7.59(2.87)$ & $9.44(3.03)$ & $9.33(3.16)$ & & & \\
\hline & Total & $6.44(2.77)$ & $7.89(2.9)$ & 8.54 (2.95) & $8.57(3.25)$ & & & \\
\hline \multirow{3}{*}{ Fruits } & Male & $6.57(1.39)$ & $9.0(2.56)$ & $8.75(1.7)$ & $8.43(2.3)$ & \multirow{3}{*}{$\begin{array}{c}\mathrm{F}=3.21 \\
p=0.076 \\
\eta_{\mathrm{p}}{ }^{2}=0.033\end{array}$} & & $F=1.253$ \\
\hline & Female & $8.0(3.03)$ & $8.71(2.08)$ & $9.22(2.8)$ & $10.89(3.76)$ & & $p=0.045$ & $p=0.332$ \\
\hline & Total & $7.6(2.72)$ & $8.86(2.32)$ & $9.21(2.43)$ & $9.93(3.22)$ & & $\eta_{\mathrm{p}}{ }^{2}=0.101$ & \\
\hline & Male & $24.0(9.07)$ & $27.56(4.5)$ & 30.88 (10.95) & $29.29(8.12)$ & $F=1.69$ & $\mathrm{~F}=2.39$ & $\mathrm{~F}=0.027$ \\
\hline Total & Female & $26.89(9.16)$ & $30.12(5.25)$ & $32.94(8.8)$ & $30.78(9.82)$ & & & \\
\hline & Total & $26.08(9.05)$ & $28.8(4.98)$ & $32.83(9.43)$ & $29.14(9.03)$ & & & \\
\hline Total Rights & Male & $28.86(6.28)$ & $43.33(6.09)$ & $37.38(8.16)$ & $51.14(10.81)$ & $F=1.38$ & $F=9.17$ & $\mathrm{~F}=1.45$ \\
\hline (Phonetic & Female & 37.17 (11.14) & $40.0(12.97)$ & $42.17(10.86)$ & $52.22(15.27)$ & $p=0.243$ & $p<0.001$ & $p=0.223$ \\
\hline $\begin{array}{l}+ \\
\text { Semantic) }\end{array}$ & Total & $34.84(10.6)$ & 41.71 (10.03) & $41.04(10.55)$ & 51.07 (13.59) & & $\eta_{\mathrm{p}}^{2}=0.226$ & \\
\hline
\end{tabular}

with the number of evoked words beginning with "A" $(r=407, p<0.01)$ and weak correlation of evoked words beginning with " $\mathrm{M}$ " $(r=0.376, p<0.01)$. Only for Age and evoked animal names a statistically significant correlation was found $(r=0.137, p>0.05)$.

\section{Discussion}

This study aimed to investigate the performance of children aged 7-10 years in verbal fluency tasks. As stated earlier, verbal fluency tasks are being widely 


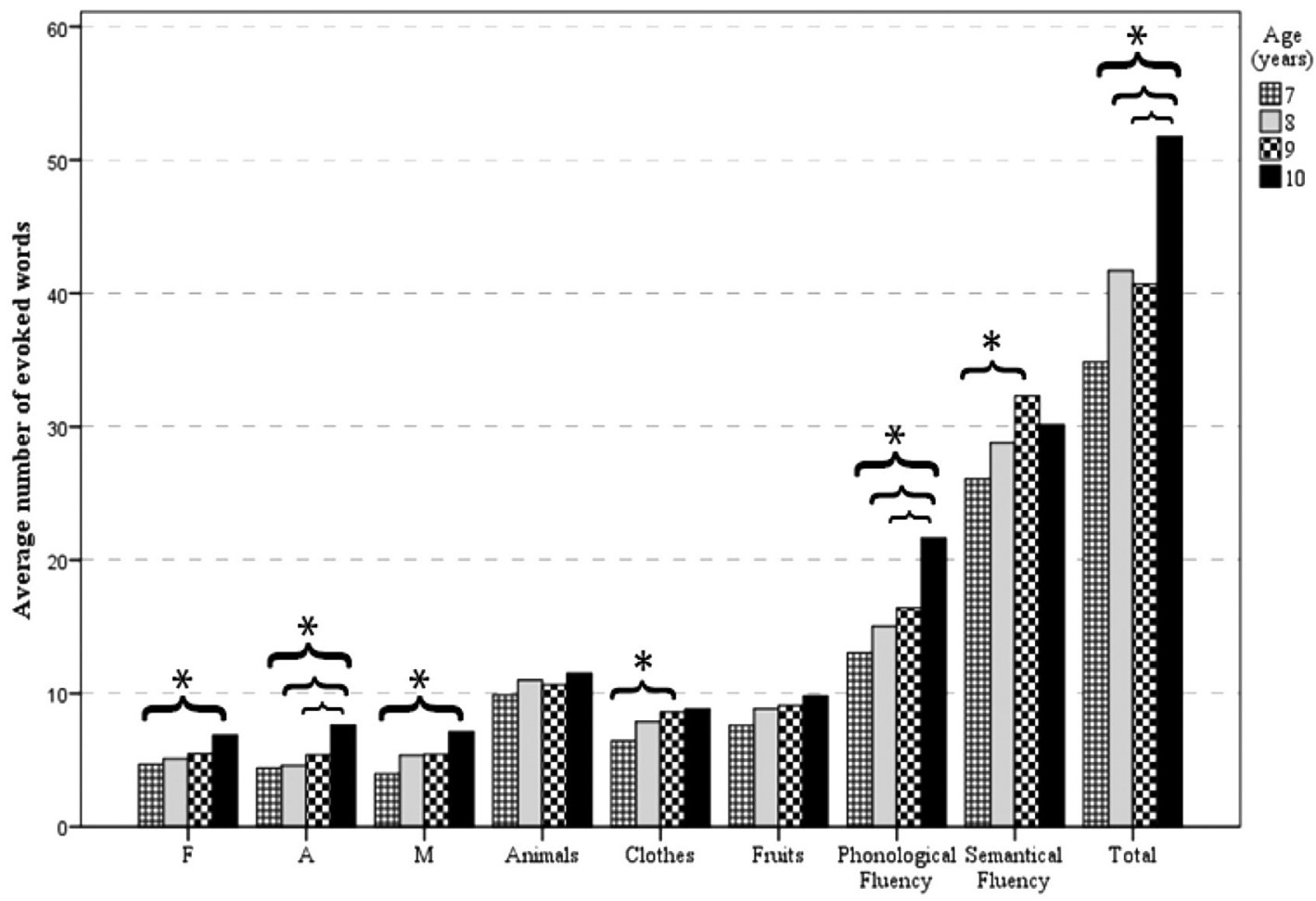

Figure 1. Average of the groups in scores of the verbal fluency test. Pairs of groups connected by the braces presented statistically significant difference (asterisks represent $p<0.05$ ).

Table 2

Correlations between the Performance and Age in Verbal Fluency Tasks

\begin{tabular}{|c|c|c|c|c|c|c|c|c|c|}
\hline & F & $\mathbf{A}$ & $\mathbf{M}$ & $\begin{array}{l}\text { Phonological } \\
\text { Fluency }\end{array}$ & Animals & Clothes & Fruits & $\begin{array}{l}\text { Semantic } \\
\text { Fluency }\end{array}$ & Total \\
\hline Age & $.297 * *$ & $.407 * *$ & $.376^{* *}$ & $.435 * *$ & 0.137 & $.276^{* *}$ & $.256^{* *}$ & $.224 *$ & $.395 * *$ \\
\hline $\mathbf{F}$ & & $.566^{* *}$ & $.539^{* *}$ & $.822 * *$ & $.279 * *$ & $.229 *$ & $.297 * *$ & $.338^{* *}$ & $.578^{* *}$ \\
\hline A & & & $.566^{* *}$ & $.853 * *$ & $.225^{*}$ & $.226^{*}$ & $.301 * *$ & $.272^{* *}$ & $.631 * *$ \\
\hline $\mathbf{M}$ & & & & $.841 * *$ & $.249 *$ & .149 & $.230^{*}$ & $.232 *$ & $.581^{* *}$ \\
\hline $\begin{array}{l}\text { Phonological } \\
\text { Fluency }\end{array}$ & & & & & $.296 * *$ & $.239 *$ & $.333^{* *}$ & $.333^{* *}$ & $.713 * *$ \\
\hline Animals & & & & & & $.316^{* *}$ & $.288^{* *}$ & $.604 * *$ & $.568^{* *}$ \\
\hline Clothes & & & & & & & $.352 * *$ & $.559 * *$ & $.561 * *$ \\
\hline Fruits & & & & & & & & $.540 * *$ & $.586^{* *}$ \\
\hline $\begin{array}{l}\text { Semantic } \\
\text { Fluency }\end{array}$ & & & & & & & & & $.343 * *$ \\
\hline
\end{tabular}

Note. $*$ indicates $p<0.05$ and $* *$ indicates $p<0.01$. The values in bold signal moderate, strong and very strong correlations. 
used for the assessment of executive functions, since these tests have proved to be sensitive enough to detect both executive losses resulting from injuries in frontal and temporal areas as well as executive dysfunctions associated with neuropsychiatric conditions (Lezak et al., 2012; Troyer, 2000; Troyer et al., 1997; Troyer et al., 1998).

The literature points that greater difficulties in phonological verbal fluency tasks are expected when compared to the semantic variant (Lezak et al., 2012; Riva et al., 2001; Koren et al., 2005; Charchat-Fichman et al., 2011). The results obtained in this study are consistent with these previous findings, given that the children studied had better results in the total words evoked in semantic verbal fluency task when compared to the results in phonological verbal fluency task.

It is believed that the phonological fluency tests become more complex because they require the most significant operations of the executive functions, notably metalinguistic skills. In addition, differences in the organization of the two tasks seem to underlie this discrepancy: given that it is more structured and requires concrete elements, semantic fluency suggests the conceptual categorization strategy of evoked words in advance, circumscribing the search possibilities and facilitating access to the verbal lexicon.

On the other hand, in addition to a less structured character, phonological fluency task becomes even more complex for presenting restrictions, requiring inhibition of inappropriate responses and monitoring of the activity. Thus, the subjects able to develop strategies to guide the evocation of words, and more competent in inhibiting impulses and monitoring the realization of the task, tend to perform better (Lezak et al., 2012; Riva et al., 2001).

In this context, the realization of phonological variant of the verbal fluency test is more closely related to the maturation of the frontal lobe of the cerebral cortex. This region is developed intensively between six and eight years, starting its myelination at about twelve months and reaching its apex of neurological maturity at around 20 years of age (Fuentes, Malloy-Diniz, Camargo, \& Cosenza., 2008; Papazian, Alfonso, $\&$ Luzondo, 2006). Based on evidence from functional imaging, it is considered that there are five periods of rapid growth in the frontal lobes that result in increasing the number of connections thereto.

During the first three years of life there are significant maturational changes in the prefrontal cortex, especially in inhibitory control ability (Diamond,
2002). According to the author, the first growth spurt happens at five years of age, which corresponds to significant gains in terms of attention control processes. The period between seven and nine years old correspond to the second growth spurt, consistent with the development of three other executives areas: information processing, cognitive flexibility and goal setting. These executive areas reach maturity and the executive control emerges between eleven and thirteen years old, which corresponds to the third spurt of the prefrontal maturation.

The data presented in this study is in line with such developmental evidence, since significant effect of age was found on the performance of participants in verbal fluency tasks, especially in phonological fluency tasks in which this effect showed greater expressiveness across all scores. Thus, the children investigated tended to show standard performance between seven and ten years in phonological fluency, a result possibly underlined to the frontal maturation and subsequent development of executive functions. This result is consistent with recent studies that indicate age as one of the main variables influencing performance on verbal fluency tasks (Diamond, 2013; Lezak et al., 2012).

Also noteworthy is that, in post hoc analysis of the influence of the age variable on the performance of the participants (comparisons peer-to-peer), a there was a greater number of significant contrasts between the scores of phonological verbal fluency task. This differentiation was more evident for the letter "A", which may underlie the increased availability of words with this letter in the Portuguese language and therefore a greater possibility of expression of maturational effect on this task. For this letter, significant contrasts between the performance of the groups 7 and 10, 8 and 10 and 9 and 10 were observed. Among the children assessed, it was observed that between 7-9 years-old, age consecutive jumps $(7-8,8-9)$ do not present significant differences in terms of development of verbal fluency. On the other hand, the age of 10 years is a milestone in development, as contrasted with all other ages, which possibly reflects cognitive advances coming from the second spurt of development of the prefrontal cortex, between seven and nine years as postulated Diamond (2002).

At the same time, it is observed that the effect of the age variable on the performance of semantic verbal fluency task is not very expressive in the sample. As stated earlier, the implementation of the semantic verbal fluency tasks relies significantly on the performance of 
verbal semantic memory systems (conceptual knowledge, storage and clustering of words), predominantly dependent on the activity of the temporal lobe (Lezak et al., 2012). Since it is known that temporal lobe and semantics long-term memory systems have critical maturational pathway at an earlier time of development when compared with the frontal functions (Mello, 2008), this result demonstrates neurodevelopmental coherence.

Unlike the executive functions - that have their maturation process prolonged to the third decade of life - the explicit memory systems (among which may be included verbal semantic memory) and anatomical regions important for their performance, such as the temporal lobe and the hippocampus, begin to develop around eight to 12 months of age and reach the structure and operation close to those of an adult between 2 and 8 years of age. For this function, the most significant progress will occur over the first five years (Mello, 2008). This fact may explain the absence of significant age variable effects on the semantic verbal fluency test among the children investigated in this study, whose maturation context is presumably functioning properly in this area.

With regard to gender, no significant effects of this variable were found on the performance on tests of verbal fluency, consistent results with findings resulting from prior studies (Nieto et al., 2008; Malloy-Diniz et al., 2007; Heleno, 2006; Koren et al., 2005; Riva et al., 2001).

\section{Final Considerations}

The verbal fluency tasks are of great value to the neuropsychological area. Its use is widely exploited in Brazil and the world, notably due to its low cost and high sensitivity in detecting changes in complex cognitive functions before injuries and / or frontal or temporal dysfunctions. However, Brazil, and more even the northeast region, still lacks normative data in tasks of this nature aimed at the child population. In this regard, the present study aimed to investigate the performance of Brazilian children from the northeastern region in phonological and semantic verbal fluency tasks.

Overall, it was observed that children performed better on verbal semantic fluency tasks compared to the phonological variant. This result is correlated with both the different nature, in terms of complexity, and with different cognitive demands of the task. Semantic verbal fluency tasks predominantly require the performance of verbal semantic memory, while the phonological verbal fluency tasks depend more specifically on the role of executive functions, particularly planning and cognitive flexibility.

In terms of development, explicit memory systems and their anatomical-functional substrate present a shorter and early maturation route, while the executive functions and the frontal lobe have long development into adulthood. This fact may explain the better performance of children in the semantic verbal fluency tasks and little expression of the influence of the variable age, since the required memory systems are already consolidated at approximately 8 years of age (Mello, 2008). By contrast, there is underperformance in phonological verbal fluency tasks and a significant effect of the age variable on all the scores, which suggests an ascending pattern of performance according to the child's age, probably corresponding to the maturation pathway of the frontal lobe that is still underway in the age group studied.

The data presented are therefore consistent with previous findings, especially those obtained by Charchat-Fichman et al. (2011), and reinforce the importance of verbal fluency tasks in the field of neuropsychological diagnosis. For developmental neuropsychology this task assumes utmost importance in view of the possibility of identifying performance standards related to the child's age and maturational context of the Brazilian National Culture System, both in normal and pathological conditions. This knowledge can contribute to a better identification of executive dysfunction in case of development in pathological conditions and can assist in proposing more refined strategies of neuropsychological intervention.

It is suggested, for further study, an expansion of the sample, contemplating ages before and after to those assessed in this study. With this strategy, the development of semantic verbal fluency can be investigated in early maturational stages (before age five), as well as identification of progression of the development of phonological verbal fluency in late maturation stages, investigating at what age this function takes on a development plateau and whether this route is consistent with the prefrontal cortex maturation period. We further recommend a larger sample in order to contemplate children of different socioeconomic situations, notably through the inclusion of subjects from the public school system, aiming at investigating the verbal fluency development in the context of different sociocultural inserts. In the same direction, expansion of the variables is recommended, especially those that would 
allow the investigation of the influence of sociocultural factors on performance in verbal fluency tasks. Finally, it is believed that the study of the development of verbal fluency in clinical populations, particularly those with executive dysfunction, can be particularly useful for the developmental neuropsychology, and may contribute to a greater understanding of the development of executive functions in typical or atypical conditions, and reflect a greater refinement of neuropsychological intervention strategies in situations of this nature.

\section{References}

Ardilla, A., Rosselli, M., Matute, E., \& Guajardo, S. (2005). The influence of the parents' educational level on the development of executive functions. Developmental Neuropsychology, 28(1), 539-560. Retrieved from http://www.ncbi.nlm.nih.gov/ pubmed/15992255

Baldo, J. V., Schwartz, S., Wilkins, D., \& Dronkers, N. F. (2006). Role of frontal versus temporal cortex in verbal fluency as revealed by voxel-based lesion symptom mapping. Journal of the International Neuropsychological Society, 12, 896-900.

Birn, R. M., Kenworthy, L., Case, L., Caravella, R., Jones, T. B., Bandettini, P. A., et al. (2010). Neural systems supporting lexical search guided by letter and semantic category cues: A self-paced overt response fMRI study of verbal fluency. Neuroimage, 49, 1099-1107. Retrieved from http://www.ncbi. nlm.nih.gov/pmc/articles/PMC2832834/

Brucki, S. M. D., \& Rocha, M. S. G. (2004). Category fluency test: Effects of age, gender and education on total scores, clustering and switching in Brazilian Portuguese-speaking subjects. Brazilian Journal of Medical and Biological Research, 37, 1771-1777. doi: 10.1590/S0100-879X2004001200002

Charchat-Fichman, H. C. Oliveira, R. M., \& Silva, A. M. (2011). Performance of Brazilian children on phonemic and semantic verbal fluency tasks. Dementia e Neuropsychologia, 5(2), 78-84. Retrieved from http://www.demneuropsy.com.br/imageBank/ $\mathrm{PDF} / \mathrm{v} 5 \mathrm{n} 2 \mathrm{a} 04 . \mathrm{pdf}$

Davidson, P. S. R., Gao, F. Q., Mason, W. P., Winocur, G., \& Anderson, N. D. (2008). Verbal fluency, Trail Making, and Wisconsin Card Sorting Test performance following right frontal lobe tumor resection. Journal of Clinical and Experimental Neuropsychology,
30, 18-32. Retrieved from http://www.ncbi.nlm. nih.gov/pubmed/17852589

Diamond, A. (2002). Normal development of prefrontal cortex from birth to young adulthood: Cognitive functions, anatomy, and biochemistry. In D. T. Stuss and R. T. Knight (ED.), Principles of frontal lobe function (pp. 466-503). Oxford: Oxford University Press.

Diamond, A. (2013). Executive Functions. Annual Review of Psychology, 64, 135-68. doi:10.1146/ annurev-psych-113011-143750.

Dias, N. M (2009). Avaliação neuropsicológica das funções executivas: Tendências desenvolvimentais e evidências de validade de instrumentos (Unpublished dissertation). Universidade Presbiteriana Mackenzie, São Paulo, Brazil.

Fuentes, D., Malloy-Diniz, L. F., Camargo, C. H. P., \& Cosenza, R. M. (2008). Neuropsicologia: teoria e prática (p. 432). Porto Alegre: Artmed.

Fuhs, M. W., \& Day, J. D. (2011). Verbal ability and executive functioning development in preschoolers at head start. Developmental Psychology, 47(2), 404416. Retrieved from http://eric.ed.gov/?id=EJ933853

Geurts H. M., Verté, S., Oosterlaan, J., Roeyers, H. \& Sergeant, J. A. (2004). How specific are executive functioning deficits in attention deficit hyperactivity disorder and autism? Journal of Child Psychology and Psychiatry, 45, 836-854. Retrieved from http:// eric.ed.gov/?id=EJ951630

Hair, J. F., Black, W. C., Babin, B. J., \& Anderson, R. E. (2010). Multivariate data analysis. (1 $\left.1^{\mathrm{a}} \mathrm{ed}.\right)$. New Jersey: Prentice Hall.

Heleno, C. T. (2006). Fluência verbal semântica em pré-escolares: Estratégias de associação (Unpublished Dissertation). Universidade Federal de Minas Gerais, Minas Gerais, Brazil.

Koren, R., Kofman, O., \& Berger A. (2005). Analysis of word clustering in verbal fluency of schoolaged children. Archives of Clinical Neuropsychology 20, 1087-1104. doi:10.1016/j.acn.2005.06.012

Lezak, M. D., Howieson, D. B., Bigler, E. D., \& Tranel, D. (2012). Neuropsychological Assessment ( $\left.5^{\mathrm{a}} \mathrm{Ed}\right)$. New York: Oxford University Press.

Malloy-Diniz L. F., Bentes, R. C., Figueiredo, P. M., Brandão-Bretas, D., Costa-Abrantes, S., Parizzi, A. M., Borges-Leite, W., \& Salgado, J. V. (2007). 
Normalización de una bateria de tests para evaluar las habilidades de comprensión del lenguaje, fluidez verbal y denominación en niños brasileños de 7 a 10 años: resultados preliminares. Revista de Neurologia, 144, 275-280. Retrieved from https://dialnet. unirioja.es $/$ servlet/articulo?codigo $=2260073$

Marzocchi, G. M., Oosterlaan, J., Zuddas A., Cavolina, P., Geurts, H., Redigolo, D., Vio C., \& Sergeant, J. A. (2008). Contrasting deficits on executive functions between ADHD and reading disabled children. Journal of Child Psychology and Psychiatry 49, 543-552. doi: 10.1111/j.1469-7610.2007.01859.x

Mello, C. B. (2008). Memória. In M. Muszkat \& C. B. de Mello (ED.), Neuropsicologia do Desenvolvimento e suas interfaces (pp. 158-172). São Paulo: All Print.

Mitrushina, M. N., Boone K. B., \& D’Elia, L. F. (1999). Handbook of normative data for neuropsychological assessment. New York: Oxford University Press.

Micelli, G., Caltagirone, C., Gaianotti, G., Masulo, C., \& Silveri, M. C. (1981). Neuropsychological correlates of localized cerebral lesions in aphasic brain damaged patients. Journal Clinical Neuropsychology 3, 53-63 doi: 10.1080/01688638108403113

Nieto, A., Galtier, I., Barroso, J., \& Espinosa, G. (2008). Fluencia verbal en niños españoles en edad escolar: Estudio normativo piloto y análisis de las estrategias organizativas. Revista de Neurologia, 46, 2-6.

Papazian, O., Alfonso, I., \& Luzondo, R. J. (2006). Trastornos de las funciones ejecutivas. Revista de Neurologia, 42, 45-50.

Prigatano, G. P., Gray, J. A., \& Lomay, V. T. (2008). Verbal (animal) fluency scores in age-grade appropriate minority children from low socioeconomic backgrounds. Journal of the International Neuropsychological Society, 14, 143-147. doi: 10.1017/ S1355617708080089

Puentes-Rozo, P. J., Barceló-Martínez, E., \& Pineda, D. A. (2008). Características conductuales y neuropsicológicas de niños de ambos sexos, de 6 a 11 años, con trastorno por déficit de atención/ hiperactividad. Revista de Neurologia, 47, 175-184. Retrieved from https://dialnet.unirioja.es/servlet/ articulo? codigo $=2690463$

Quinn, G. P., \& Keough, M. J. (2002). Experimental Design and Data Analysis for Biologists. Cambridge (UK): Cambridge Press.
Riva, D., Nichelli, F., \& Devoti, M. (2001). Developmental aspects of verbal fluency and confrontation naming in children. Brain and Language, 71, 267-284. doi: 10.1006/brln.1999.2166

Sarsour K., Sheridan M., Jutte D., Nuru-Jeter A., Hinshaw S., \& Boyce W. T. (2011). Family socioeconomic status and child executive functions: The roles of language, home environment and single parenthood. Journal of the International Neuropsychological Society, 17, 120-132. doi: 10.1017/ S1355617710001335

Sauzéon H., Lestage, P., Raboutet, C., N'Kaoua, B., \& Claverie, B. (2004). Verbal fluency output in children aged 7-16 as a function of the production criterion: qualitative analysis of clustering, switching processes, and semantic network exploitation. Brain and Language, 89, 192-202. doi:10.1016/ S0093-934X(03)00367-5

Silva, T. B. L., Yassuda, M. S., Guimarães V. V., \& Florindo, A. A. (2010). Fluência verbal e variáveis sociodemográficas no processo de envelhecimento: Um estudo epidemiológico. Psicologia: Reflexão e Crítica, 24(4), 739-746. doi: 10.1590/ S0102-79722011000400014

Strauss, E., Sherman, E.M.S., \& Spreen, O. (2006). A Compendium of Neuropsychological Tests: Administration, Norms and Commentary (3rd ed.). New York: Oxford University Press.

Troyer, A. K., Moscovitch, M., \& Winocur, G. (1997). Clustering and switching as two components of verbal fluency: Evidence from younger and older healthy adults. Neuropsychology, 11(1), 138-46. doi: 10.1037//0894-4105.11.1.138

Troyer, A. K., Moskovitch, M., Winocur, G., Alexander, M. P., \& Stuss, D. (1998). Clustering and switching on verbal fluency: The effects of focal frontal and temporal lobe lesions. Neuropsychology, 36, 449-504. doi:10.1016/S0028-3932(97)00152-8

Troyer, A. K. (2000). Normative data for clustering and switching on verbal fluency task. Journal of Clinical and Experimental Neuropsychology, 22, 370-378. Retrieved from http://www.ncbi.nlm.nih.gov/ pubmed/10855044

Recebido em: 16/12/2014

Reformulado em: 15/05/2015

Aprovado em: 01/06/2015 
Sobre os autores:

Gilmara de Lucena Leite é psicóloga pela Universidade Estadual da Paraíba, mestre em Ciências pela Universidade Federal de São Paulo e neuropsicóloga, com o título de especialista pelo Conselho Federal de Psicologia. Atua nas seguintes linhas de pesquisa: desenvolvimento cognitivo infantil, neuropsicologia transcultural e educação.

E-mail: gilmaraleitte@gmail.com

Izabel Augusta Hazin Pires é pós-doutora pela Universitè René Descartes, coordenadora do LAPEN, vice-coordenadora da pós-graduação em Psicologia (UFRN), membro da diretoria IBNeC e integrante do GT da ANPEPP (Psicobiologia, Neurociências e Comportamento), bolsista de produtividade 2 do CNPq e atua na área de Neuropsicologia do Desenvolvimento e da Aprendizagem.

E-mail: izabel.hazin@gmail.com

Laura Carolina Lemos Aragão é psicóloga pela Universidade Federal do Rio Grande do Norte, mestranda em Psicologia pela mesma instituição, integrante do Laboratório de Pesquisa e Extensão em Neuropsicologia (LAPEN/ UFRN) e desenvolve pesquisas em Neuropsicologia do Desenvolvimento e da Aprendizagem.

E-mail: lauraclaragao@gmail.com

Artemis Paiva de Paula é psicóloga pela Universidade Federal do Rio Grande do Norte, mestranda em Psicologia pela mesma instituição, integrante do Laboratório de Pesquisa e Extensão em Neuropsicologia (LAPEN/ UFRN) e desenvolve pesquisas em Neuropsicologia do Desenvolvimento e da Aprendizagem.

Ediana Rossely de Oliveira Gomes é mestre em Psicologia pela Universidade Federal do Rio Grande do Norte, doutoranda em Psicologia pela mesma instituição, integrante do Laboratório de Pesquisa e Extensão em Neuropsicologia (LAPEN/ UFRN) e desenvolve pesquisas em Neuropsicologia do Desenvolvimento e da Aprendizagem.

E-mail:ediana.ogomes@gmail.com

Danielle Garcia é mestre em Psicologia pela Universidade Federal do Rio Grande do Norte, doutoranda em Psicologia pela mesma instituição, integrante do Laboratório de Pesquisa e Extensão em Neuropsicologia (LAPEN/ UFRN) e desenvolve pesquisas em Neuropsicologia do Desenvolvimento e da Aprendizagem.

E-mail:daniellefg@yahoo.com.br

Priscila Magalhães Barros é especialista em Neuroreabilitação pela Universidade Federal do Rio Grande do Norte, mestre e doutoranda pela mesma instituição, integrante do Laboratório de Pesquisa e Extensão em Neuropsicologia (LAPEN/ UFRN) e desenvolve pesquisas em Neuropsicologia do Desenvolvimento e da Aprendizagem.

E-mail:priscilanascimento87@yahoo.com.br

João Carlos Nascimento de Alencar é graduando em Psicologia pela Universidade Federal do Rio Grande do Norte, integrante do Laboratório de Pesquisa e Extensão em Neuropsicologia (LAPEN/UFRN) e desenvolve pesquisas em Neuropsicologia do Desenvolvimento e da Aprendizagem, Psicobiologia e Neurociências, especial interesse em métodos quantitativos de pesquisa.

E-mail: joaocarlos.alencar@hotmail.com

Helenice Charchat Fichman é doutora em Neurociências e Comportamento pela Universidade de São Paulo, coordenadora da graduação em Psicologia da PUC-Rio e atua na área de Neuropsicologia Clínica, com ênfase em desenvolvimento cognitivo e envelhecimento, avaliação e reabilitação neuropsicológica, validação e desenvolvimentos de novos instrumentos.

E-mail:hcharchat@uol.com.br

Psico-USF, Bragança Paulista, v. 21, n. 2, p. 293-304, mai./ago. 2016 
Rosinda Martins Oliveira é doutora em Psicologia Experimental pela University of Oxford, professora adjunta da UFRJ, neuropsicóloga com experiência em avaliação neuropsicológica e reabilitação cognitiva na área clínica e do trabalho e atua na área de Psicologia Cognitiva, Neuropsicologia e Avaliação.

E-mail: rosindaoli@yahoo.com.br

Contato com os autores:

Gilmara de Lucena Leite

Universidade Federal de São Paulo

Centro de Ciências Humanas Letras e Artes (CHLA)

Departamento de Psicobiologia

Rua Botucatu, 862, $1^{\circ}$ Andar, Vila Clementino

CEP: 040230-62

São Paulo-SP, Brasil 